\section{VÔO BRASILEIRO}

\section{Freud and the invention of} jewishness, de Betty B. Fuks. New York: Agincourt Press, 2008, 129 p.

\section{Ana Vicentini de Azevedo \\ Psicanalista, membro do Corpo Freudiano. Professora da Universidade Federal de São Carlos (SP).}

No prefácio à edição brasileira do inquietante poeta coreano, Yi Sáng, o tradutor Yun Jung Im traz uma reflexão importante acerca do estilo fragmentário do poeta, que, segundo alguns, produz "cacos de poesia”. Interrogando-se sobre as complexas ressonâncias dos dois ideogramas chineses para 'tradução', afirma Jung Im que "o primeiro ideograma significa 'farfalhar, voar, subverter [...], virar”' (O olho. de.corvo e outras obras poéticas de Yi Sáng, Perspectiva, 1999), ressaltando ainda que sua composição se dá a partir de 'vez'e de 'vôo'. Já o segundo ideograma para o vocábulo 'tradução' é, ele também, um composto, tendo por base duas idéias centrais: a idéia de 'palavra', por um lado, e, por outro, a de 'rede' e de 'boa fortuna'.

As observações deste tradutor oferecem um rico ponto de partida e um convite à reflexão sobre a recente tradução para o inglês do livro de Betty B. Fuks,
Freud e a judeidade: a vocação do exílio (Jorge Zahar, 2000), que em inglês recebeu o título mais conciso de Freud and the Invention of Jewishness.

À luz dos comentários de Jung Im, um primeiro aspecto se salienta: a tradução é um vôo que tece redes de palavras produzindo agitações, tremulações ou quem sabe até subversões. De fato, este é o enquadre em que podemos situar o vôo do trabalho de Fuks do Brasil para os Estados Unidos. Ele tem o privilégio de abrir uma série de publicações da recém inaugurada editora Agincourt Press, cuja orientação central é a de publicar textos “não exatamente 'de' ou 'sobre' psicanálise, mas textos que tenham interesse para o trabalho analítico, para os analistas e para aqueles que refletem sobre o impacto da psicanálise no pensamento de nosso tempo”, como declara Paola Mieli no prefácio ao livro de Fuks.

O vôo inaugural do livro de Betty Fuks traz outro atributo importante, também destacado no desdobramento dos ideogramas chineses para tradução: ele é parte importante de uma rede, rede esta de vários matizes. Em primeiro lugar, ele integra uma rede de palavras, um trabalho da palavra e com a palavra, na trilha aberta por Freud para a psicanálise. Talking cure, batizou-o Anna O. O trabalho analítico, tal qual definido por Freud em seus múltiplos contornos, tem na palavra, na rede de palavras — ou na cadeia significante, como conceitualizou-a Lacan sua espinha dorsal. O sujeito do qual se ocupa a psicanálise é o sujeito como efeito desta rede de palavras. Uma rede que será tecida na busca incessante por palavras que possam tudo dizer. Tal experiência se mostrará para esse sujeito como sempre faltosa, como "cacos da poesia", tal como posta em cena pelo trabalho poético do jovem Yi Sáng. 
Os poetas, na qualidade de artífices da linguagem - aliás, como o foi também Freud -, estão advertidos da natureza fragmentária desta rede: uma rede é "uma porção de buracos, amarrados com barbante..." como escreveu Guimarães Rosa em Tutaméia. A assunção deste vácuo que é ao mesmo tempo constitutivo e constituinte do texto literário é uma posição estética clara destes dois escritores - Yi Sáng e G. Rosa. Mas é também uma posição ética elaborada e sustentada por Freud desde os fundamentos da psicanálise, em A interpretação dos sonhos. Sempre faltará um significante que possa dizer (d)o sujeito completamente, daí este ser faltoso, esse fala-ser dividido que cria sua fala a partir do vazio, ao mesmo tempo em que o cria. Nesse ponto da rede, amarram-se poesia e psicanálise.

A ênfase lacaniana dada à ética fundadora de Freud no que se refere ao estatuto da palavra na experiência do sujeito e no trabalho analítico é retomada com vigor ao longo do livro de Fuks. O privilégio é igualmente dado ao texto, especialmente à herança advinda da tradição talmúdica do trabalho do texto e com ele. Trata-se, para Fuks, "de uma fundação ética que se assenta na primazia da palavra”.

Nesta tradição, a dialética presençaausência que marca a experiência com a palavra constitui um dos centros de confluência para a autora articular a construção freudiana com uma outra construção — a de judeidade. Em outros termos, tanto para a psicanálise como para certa vertente de interpretação da herança talmúdica, estamos muito distantes de uma posição metafísica de sustentação de uma essência, de uma fixidez, do humano, do sujeito, do "ser judeu”. Não se trata de ontologia, mas da sustentação de uma concepção da subjetividade e da linguagem como instâncias de produção de metáforas, de produção de torções na linguagem a partir do vazio e como modo de fazer frente a ele.

Para essa empreitada analítica, em seu sentido de desmontagem, ou se quisermos, com Derrida, de desconstrução, Fuks convoca ao diálogo pensadores que, não à toa, se notabilizaram justamente por teorizar o literário, tais como Derrida, Blanchot e Barthes. Para indicar a pertinência e riqueza das escolhas de Fuks na tessitura de sua densa rede de articulações, basta lembrar um comentário de Derrida em A escritura e a diferença sobre o estatuto do literário: a "experiência de conversão que instaura o ato literário escritura ou leitura, é de uma espécie tal que as próprias palavras ‘separação’ e 'exílio', designando sempre uma ruptura e um caminho no interior do mundo, não conseguem manifestá-la diretamente[,] mas apenas indicá-la por uma metáfora (...)"

Freud acentuou em $\mathrm{O}$ mal-estar na civilização que "a escrita (...) é a fala [sprache] do ausente”. É rigorosamente sob essa ótica freudiana que Fuks privilegia a dimensão da escrita (ou escritura, como preferem algumas traduções da noção francesa de écriture). Com ela nos afastamos de um mero jogo opositivo, imerso na lógica imaginária de ou/ou, como por exemplo, entre fala ou escrita; entre presença ou ausência, para torná-lo triádico: a escrita traz à baila a lógica que marca o simbólico, na medida que em ato, em presença, há não apenas presença e ausência, mas também presença do ausente, como marcou Freud.

Este traço leva-nos a um outro elemento importante do vôo do trabalho de Betty Fuks para o inglês. Mais uma vez a referência à escrita ideogramática chinesa e suas convocações ao trabalho de leitura, de tradução são pertinentes. A tradução é uma atividade de deslocamento, de transposição, como sugere o vôo. Freud cunhou 
um conceito específico para este tipo de vôo: Übertragung, transferência.

Por ser um balizador da clínica, a transferência é, desde Freud, um conceito fundamental da psicanálise, como ressaltou Lacan, daí decorrendo inclusive sua amplitude teórica. Desta amplitude, é importante destacar aqui alguns sentidos do conceito e do termo alemão que dizem respeito a Übertragung do livro de Fuks para o inglês. Um primeiro sentido da transferência remete-nos à noção de ligação. O lançamento de Freud and the Invention of Jewishness em Nova York, recentemente, é resultado de uma transferência de trabalho entre alguns analistas do Brasil e de Après-Coup Psychoanalytic Association, instituição que inclusive apoiou financeiramente sua tradução e publicação.

Sabemos das múltiplas e complexas formas de resistências ao discurso analítico nesse país, desde os comentários de Freud, notadamente em "A questão da análise leiga” (1926), até a atualidade. Nesta desmontagem da psicanálise, igualmente sabemos do papel preponderante desempenhado por alguns analistas judeus que tiveram que fugir do nazismo, emigrando para os Estados Unidos, mas não somente estes. Antes deles, Abraham A. Brill, por exemplo, judeu oriundo do império austro-húngaro e fundador da New York Psychoanalytic Society, em 1911, destaca-se como o mais forte opositor a Freud no debate sobre a questão da análise leiga. Mais tarde, nas décadas de 1950 e 60, a psicologia do eu toma fôlego ímpar com os trabalhos de Hartmann, Kris e Loewenstein. Tendo em vista tal contexto, a articulação de Betty Fuks em Freud and the Invention of Jewishness adquire um valor e uma importância ainda mais notáveis. A ética psicanalítica do rigor à palavra, à escrita, juntamente com a assunção de que "o eu não é senhor em sua própria casa” é entre- laçada com o rigor da tradução talmúdica da letra e com a "especificidade da ética judaica de abertura ao Outro”.

Traduzir essa articulação, mantendo o delicado equilíbrio entre a cadência e a fluidez da língua e o rigor conceitual traços do estilo de Fuks na versão original - é o aspecto que destaco para encerrar esse breve comentário. A Übertragung contempla também o sentido de transformar algo em sentido figurado, ou seja, de produção de linguagem figurada. Ao invés da tradução traidora, do traduttore traditore temos em Freud and the Invention of Jewishness um vôo da palavra, mantida em sua errância e dando notícia "da vocação do exílio" (preciso e precioso subtítulo de Fuks, lamentavelmente excluído da versão em inglês) que marca tanto o sujeito do inconsciente quanto a judeidade.

Recebida em 29/7/2008.

Aprovada em 5/8/2008.

Ana Vicentini de Azevedo anavica@terra.com.br 